"Mircea cel Batran" Naval Academy Scientific Bulletin, Volume XIX - 2016 - Issue 1

Published by "Mircea cel Batran" Naval Academy Press, Constanta, Romania // The journal is indexed in:

PROQUEST / DOAJ / DRJI / JOURNAL INDEX / I2OR / SCIENCE LIBRARY INDEX / Google Scholar / Crossref /

Academic Keys / ROAD Open Access / OAJI / Academic Resources / Scientific Indexing Services / SCIPIO

\title{
A SYSTEM TO MAKE USE OF EXISTING BREAKWATERS AS OVERTOPPING WAVE ENERGY CONVERTERS
}

\author{
Deniz ÜNSALAN ${ }^{1}$ \\ K. Turgut GÜRSEL ${ }^{2}$ \\ Kunsel IZET-ÜNSALAN ${ }^{3}$ \\ ${ }^{1}$ Prof. Dr. Institute of Marine Sciences and Technology, Dokuz Eylül University, İzmir, Turkey \\ ${ }^{2}$ Prof. Dr. Institute of Marine Sciences and Technology, Dokuz Eylül University, İzmir, Turkey \\ ${ }^{3}$ Assoc. Prof. Dr.Ing. Faculty of Mechanical, Industial and Maritime Engineering, Ovidius University, \\ Constanta, Romania
}

\begin{abstract}
The main purpose of building breakwaters is to produce safe havens for ships and boats in rough seas. The general architecture for a breakwater is a wall with a trapezoidal-shaped cross section extending parallel to the shoreline. As the waves from the open sea approach, they are encountered by the so-called slope and revetment of the breakwater, where the wave is broken and its energy is dissipated and/or reflected back. However, the ever-increasing attractiveness of the utilization of waves as energy sources, paralleling to the increasing monetary and environmental costs of energy, has led the authors to consider the vast amounts of this otherwise dissipated energy into useful electrical energy. A wave energy conversion concept, which can be classified as an "overtopping" wave energy converter was conceived, where the open sea-facing (revetment) side of the breakwater is fitted by a water collecting channel at a suitable height above the calm water level, running alongside the breakwater. The channel leads the collected water to a powerhouse containing a low head turbine (or a set of such turbines) discharging it to the calm water of the inner harbour. Power obtained from these turbines can be converted to electrical energy. In this study, an estimation of the volume of water collected by the channel and the energy production for a proposed breakwater - power station system for a typical rough weather shall be made.

It is deemed that the feasibility of this system is comparable to and even higher than the other wave energy conversion systems since it does not require additional facilities and power supply lines to be built due to its proximity to the existing energy transmission lines, except for the addition of new features/installations to the existing breakwaters.
\end{abstract}

Keywords: Wave energy, breakwater, runup height, wave overtopping converter.

\section{Introduction}

As coastal structures, breakwaters or seawalls are constructed to prevent the devastating effects of waves to the shoreline, as well as marine vehicles that seek a safe haven in rough weather conditions. They are almost invariantly erected parallel to the shoreline, where the waves are normal or almost normal to them.

However, ever-increasing dearth of energy, as witnessed by the escalation of struggles for oil and gas (prices) and the quest for non-carbon dioxide emitting power systems has interested the interest in renewable energy sources, wave energy being one of them. Recently, wave energy stations have become a reality, despite the problems of high amount of investment required, difficulty in maintenance/repair, survivability in storm conditions and the relatively long distances to the existing power grid.

As a result, many types of the wave energy converters (WECs) and their generators have been manufactured. The problems related with electrical generation segment are eliminated in some WECs by keeping most of the costly electrical components on-shore where they are

DOI: 10.21279/1454-864X-16-I1-052

(c) 2015. This work is licensed under the Creative Commons Attribution-Noncommercial-Share Alike 4.0 License. protected from the severe marine environment and can be easily serviced. Such configurations are alternatives to the systems connected to the grid by undersea cabling. As another measure for sheltering the electrical components and enhancing the probability of continuous power supply, certain types of the WECs supply energy by pumping seawater into a coastal reservoir at a suitable height above the calm water level, running through a channel into a low head hydropower turbine for solving the general problem of fluctuating output in wave energy

As a less sophisticated alternative to the types of these WECs above-mentioned, modification of existing breakwaters used to protect harbours, wharfs, beaches and marinas has been conceived. Instead of using breakwaters as a wave deflector, using them as a collector of seawater at some height above the calm water line has been considered. This approach places such a wave energy system into the "wave overtopping" class [1].

The system proposed takes mainly the southern shoreline of the Black Sea coast into consideration. This area, where the mountain 
"Mircea cel Batran" Naval Academy Scientific Bulletin, Volume XIX - 2016 - Issue 1

Published by "Mircea cel Batran" Naval Academy Press, Constanta, Romania // The journal is indexed in:

PROQUEST / COPE / DRJI / JOURNAL INDEX / I2OR / SCIENCE LIBRARY INDEX / Google Scholar / Academic Keys / ROAD Open Access / OAJI / Academic Resources / Scientific Indexing Services / SCIPIO

ranges extend parallel to the sea, with narrow or no coastal planes and with a rapidly deepening sea, hosts many settlements having strong interests with the sea. Such settlements have a number of artificial harbours for ships and for fishing craft of different capacities which are separated from the open sea by breakwaters. This area is open to the seas created by the northern winds, with a considerable fetch and the tidal variation of sea height, which does not significantly affect the performance of the system [2].

\section{Wave runup formulae}

The maximum height reached by the $2 \%$ of incident waves perpendicular to a shoreline, $\mathrm{R}_{\mathrm{u} 2 \% \text {, }}$ is given by Van der Meer [3] as:

$$
R_{u 2 \%}=1.5 \gamma_{f} \gamma_{b} H_{s} \frac{\tan \alpha}{\sqrt{s}}
$$

where $\gamma_{f}$ and $\gamma_{b}$ are reduction factors accounting for friction and for the existence of a berm, respectively, $H_{\mathrm{s}}$ is the significant wave height, $\alpha$ is the slope of the shoreline and $s$ is the wave steepness. In terms of the volumetric flux $Q$ over a breakwater, the same author proposes the correlation:

$$
\frac{Q}{\sqrt{g H_{s}^{3}}}=\frac{0.06}{\sqrt{s}} \gamma_{b} e^{-4.7 \frac{R_{c}}{H_{s}} \cdot \frac{\sqrt{s}}{\tan \alpha} \cdot \frac{1}{\gamma_{b} \gamma_{f}}}
$$

where $R_{\mathrm{c}}$ is the freeboard of the coastal structure, $\gamma_{\mathrm{b}}$ and $\gamma_{\mathrm{f}}$ are the factors as explained above. Kofoed [4] proposes an approximate value for wave fronts almost perpendicular to the breakwater without any berm and with a smooth surface as:

$$
\frac{Q}{\sqrt{g H_{s}^{3}}}=0.2 e^{-2.3 \frac{R_{c}}{H_{s}}}
$$

The hydraulic energy potential obtainable by a shore structure, involving a water collecting channel above the still water level as shown in the figure 1 is:

$$
P_{\text {available }}=\rho g Q R_{c}
$$

The optimum channel height for a given significant wave height can be obtained by substituting Equation (3) into Equation (4) and taking derivatives with respect to $R_{c}$ :

$$
\frac{d P_{\text {available }}}{d R_{c}}=\rho g\left(Q+R_{c} \frac{d Q}{d R_{c}}\right)=0
$$

From which the optimum channel height can be derived as:

$$
R_{c}=\frac{H_{s}}{2.3}
$$

Energy potential per meter of such a watercollection canal is:

$$
P_{\max }=0.032 \rho g^{\frac{3}{2}} H_{s}^{\frac{5}{2}}
$$

The water collected by the channel running along the breakwater can be delivered to a power station, with a low-head turbine (for example, a Kaplan turbine) discharging into the calm waters of the inner harbour.

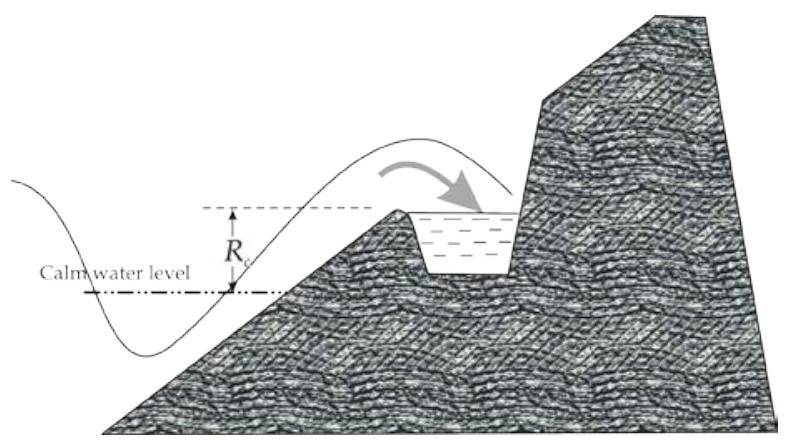

Figure 1. Cross section of the breakwater with the collection channel

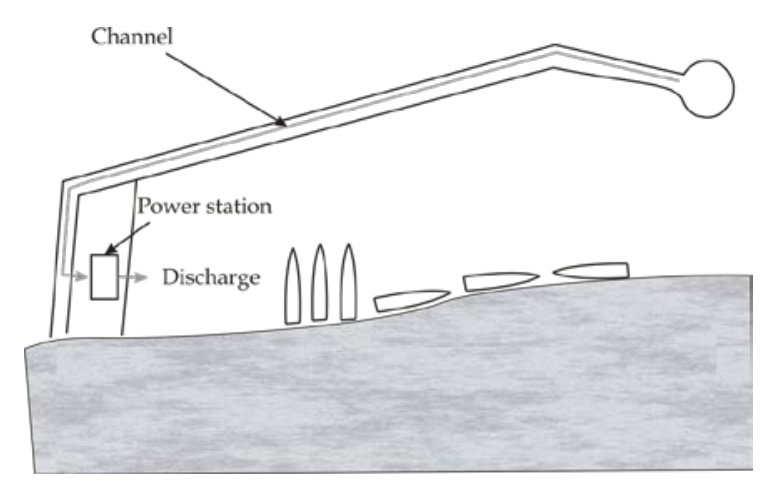

Figure 2. General layout of the system

\section{An illustrative example for the WEC investigated}

Figures 1 and 2 are the illustrations of this concept. As an illustrative example, for a breakwater where design significant wave height selected from an analysis of the yearly-averaged wave state (significant wave height) is 1.5 meters, the channel height $\left(R_{\mathrm{c}}\right)$ shall be 0.65 meters from equation (6). Expected runup water flux into the channel is estimated $0.423 \mathrm{~m}^{3} / \mathrm{s}$ per meter of channel length from equation (3). For an effective channel span of 200 meters, the total flow rate shall amount to $84.7 \mathrm{~m}^{3} / \mathrm{s}$. Energy potential is 555 
"Mircea cel Batran" Naval Academy Scientific Bulletin, Volume XIX - 2016 - Issue 1

Published by "Mircea cel Batran" Naval Academy Press, Constanta, Romania /l The journal is indexed in:

PROQUEST / COPE / DRJI / JOURNAL INDEX / I2OR / SCIENCE LIBRARY INDEX / Google Scholar / Academic Keys / ROAD Open Access / OAJI / Academic Resources / Scientific Indexing Services / SCIPIO

kW for this facility. A well-designed power-takeoff system with Kaplan or propeller turbine can ensure efficiencies of about 90 percent, indicating
$500 \mathrm{~kW}$ of power can be obtained from such a facility in sea states exceeding the design significant wave height.

\section{CONCLUSIONS}

In this study, modification of existing breakwaters used to protect harbours, wharfs, beaches and marinas as overtopping WECs has been conceived. Instead of only using breakwaters as a wave deflector, using them as a collector of seawater at some height above the calm water line has been considered. A channel leads the collected water to a powerhouse containing a low head turbine discharging it to the calm water of the inner harbour whereas the power obtained from this turbine can be converted to electrical energy.

It has been shown that even for a modest sea state, an economically justifiable energy can be obtained by a modification of the existing breakwaters. It is proposed that an existing small harbour should be selected as a prototype station and necessary modifications including a water collection channel on the revetment side of the breakwater and powerhouse with the turbine and electrical generator be established. Since the whole system will need very low maintenance and repair costs and be capable of bearing up against storm conditions, it is deemed that such a facility shall have a relatively short period of payback.

\section{BIBLIOGRAPHY}

[1] Graw, K.-U.: Wellenenergie - Eine hydromechanische Analyse, Institut für Grundbau, Abfall- und Wasserwesen, Bergische Universität - Gesamthochschule Wuppertal, ISSN 0179-9444, 1995.

[2] Pashova, L., Popova, S. "Daily sea level forecast at tide gauge Burgas, Bulgaria using artificial neural networks", Journal of Sea Research 66 (2011) 154-161.

[3] Van der Meer, Jentsje W. "Wave run-up and overtopping.", Dikes and Revetments: Design, Maintenance and Safety Assessment, ed. KW Pilarczyk (AA Balkema, Rotterdam, The Netherlands) (1998) $145-159$.

[4] Kofoed, J.P., "Wave Overtopping of Marine Structures-Utilization of Wave Energy", Doctoral thesis, Hydraulics and Coastal Engineering Laboratory, Department of Civil Engineering, Aalborg University, Denmark, December 2002. 